\title{
Use of Multiple Intelligence Modalities to Convey Genetic and Genomic Concepts in African American College Biology Students
}

\author{
Jabril Johnson', Fatimah Jackson² \\ ${ }^{1}$ Department of Genetics, Howard University, Washington DC, USA \\ ${ }^{2}$ Department of Biology, Howard University, Washington DC, USA \\ Email: jabril.johnson1@gmail.com, fatimah.jackson@howard.edu
}

Received 10 April 2015; accepted 1 June 2015; published 4 June 2015

Copyright (C) 2015 by authors and Scientific Research Publishing Inc.

This work is licensed under the Creative Commons Attribution International License (CC BY). http://creativecommons.org/licenses/by/4.0/

c)

\begin{abstract}
Correct conceptualizations of genetics and genomics are central to understand many aspects of the STEM disciplines as they provide the foundational building blocks for later work in the life sciences. Our study of $\mathbf{4 3 5}$ African American college students investigated the use of culturallyrelevant memes transmitted using multiple intelligence (MI) modalities to convey core genetic and genomic information as an alternative to the traditional teaching approaches. We observed that this approach appears to optimize the transmission and retention of core genetics concepts, identify and correct misconceptions, and serve as a conduit to increased African American (AA) access to further studies in STEM disciplines. A review of the relevant literature and specific examples of our interventions and their MI links are provided.
\end{abstract}

\section{Keywords}

STEM, Genetics, Minority Science Education, African American Education

\section{Introduction: Genetic Concepts and the STEM Disciplines}

Advances in genetics and genomics, in the past decade, have dramatically increased the impact of genetic information on society as a whole and understanding of the science, technology, engineering, and mathematics (i.e., STEM) disciplines in particular. Although genetic exposure has increased in modern day society, recent studies show that the general public's knowledge and understanding of genetic concepts remain relatively low. Studies also show that primary and secondary school students have many conceptual problems and misconceptions concerning cell biology and genetics [1]-[4] that subsequently limit their access to STEM disciplines. Spe- 
cifically, a majority of students and teachers evaluated terms such as gene, DNA, chromosome, and cell division as difficult to learn [5]. Once misconceptions of these terms and their applications are formed, they can become persistent and adversely affect the student's current and future science learning. This is very alarming considering that concepts linked to cell division, DNA, chromosome and genes, for example, are crucial to a clear understanding of many dynamics of life and are gateway concepts for many STEM disciplines (see Figure 1).

Over the years, however, little has changed in the way in which these subjects are taught and their comprehension has not improved [6]. A partnership between the National Society of Genetic Counselors and the American Society of Human Genetics investigated high school students across the nation that participated in an essay writing contest as part of a National DNA Day [7]. A thorough analysis of 500 submitted essays (from 2443 over 2 year contest) revealed that students from 2007 had the same genetic misconceptions as students in 2000 (from a comparable study by the National Assessment of Educational Process).

This lack of progress in understanding genetics and genomics supports the idea that a change in the curriculum is needed. The teacher plays an important role in developing the student's ideology of genetic concepts as well as in creating an active learning environment that is responsive to the multiple learning styles that exist inherently in the classroom. Given the inclusiveness of US higher education, addressing student's multiple learning styles is as important among college students today as it has been shown to be among primary and secondary school students. Yet, there are many misconceptions in student's understanding of genetics and genomics that are often resistant to elimination through traditional teaching strategies and methods [4] [8] [9]. These traditional approaches rely on appeals to our verbal-linguistic and logical-mathematical intelligences. Gardner [10] has defined these modalities as: Verbal-Linguistic (Word Smart)—students who possess this learning style learn best through reading, writing, listening, and speaking. Verbal students absorb information by engaging with reading materials and by discussing and debating ideas. Logical-Mathematical (Logic Smart)—students who exhibit this type of intelligence learn by classifying, categorizing, and thinking abstractly about patterns, relationships, and numbers [11].

For effective $21^{\text {st }}$ Century science teaching, new strategies such as conceptual maps, conceptual networks, semantic features analysis, and conceptual change in text are needed [12]-[14]. Lesson plans that address the multiple intelligences (MIs) present in the class should be considered [15] [16]. In addition to these changes in strategies and approach, Dikmenli [4] demonstrates that students can reveal what they know and understand through drawings and that this spatial approach addressing can be used to identify misconceptions before they become a hindrance to correct learning. Thus an important tool necessary to address misconceptions in the class would be to have the students draw, at the end of the lesson, a key idea of the lecture [17]-[20].

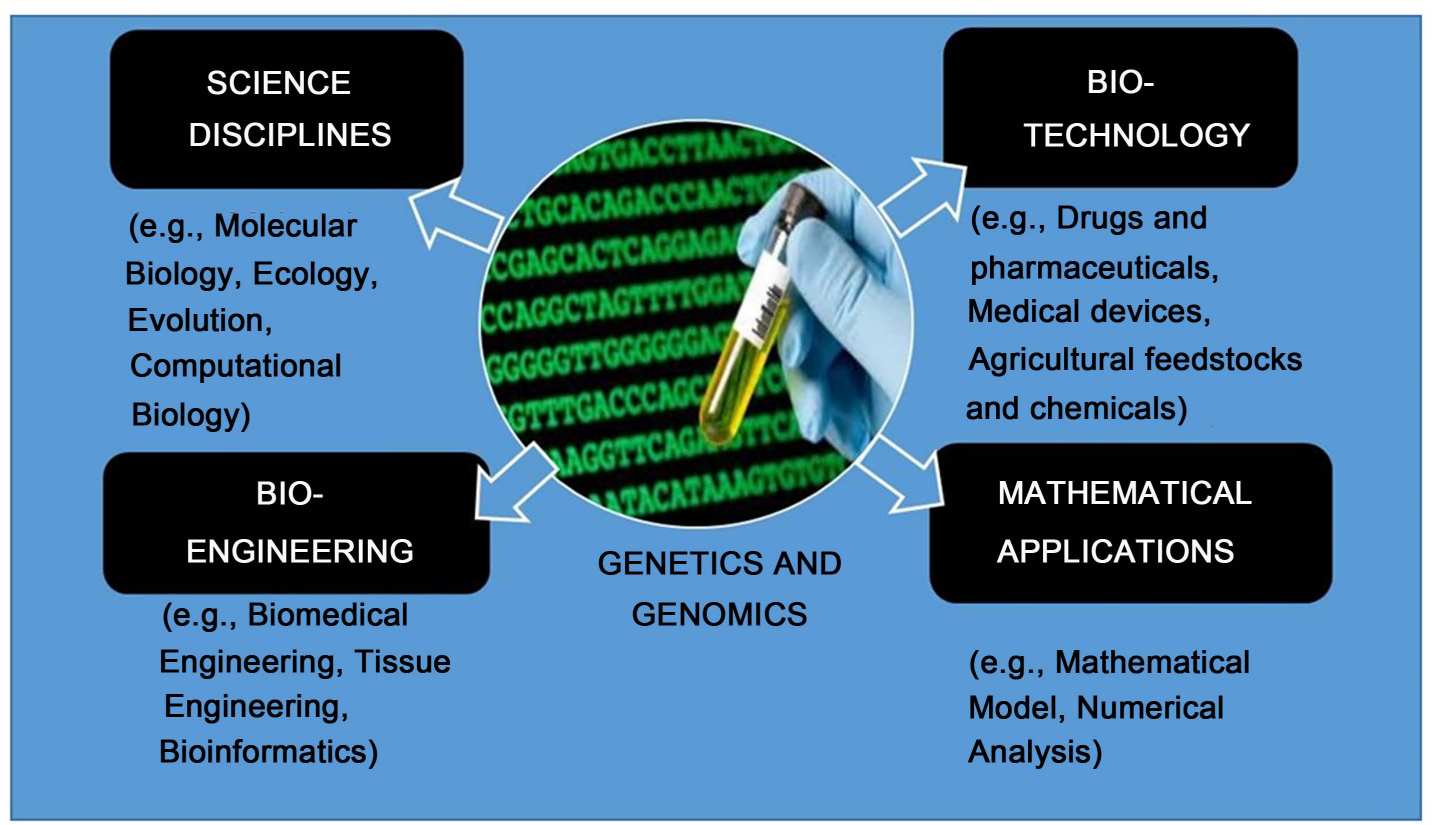

Figure 1. Centrality of genetics and genomics to the STEM disciplines. 


\subsection{Underrepresented Ethnic Minorities in STEM Disciplines}

According to a 2010 report from the National Academies, the competitive position of the US in Science continues to decline and the nation needs a sustained commitment to investment in educational innovation. An update on the influential 2005 report Rising Above the Gathering Storm: Energizing and Employing America for a Brighter Future, science education and basic research are paramount in this new emphasis [21]. This situation presents an issue to not only for the national economy but also all aspects of the social and cultural identity of the United States. The National Science Foundation (NSF) published statistical data analyzing Women, Minorities, and Persons with Disabilities in Science and Engineering for 2013 showed a decline in the success of minority undergraduate students in their science careers of choice compared to their non-Hispanic white counterparts. Since the majority of AAs in sciences received their training at minority-serving institutions, such as the historically black colleges and universities (HBCUs), the interpretation of these data expose a dilemma within such schools. In recent years, these institutions have experience declines in the number of undergraduates earning bachelors of science degrees after having had a significant institutional history of producing substantial numbers of doctoral-level AAs in the life sciences [22]. The NSF also reported that minorities earning science and engineering bachelor's degrees at minority-serving institutions decreased 27\% to 19\% from 2001-2010. This alarming decline in science bachelor degrees earned by AAs in HBCU's is recognized as an important yet often misunderstood problem [23]. What has changed?

The roots of this decline rest in large measure the high school and undergraduate science curriculums of many of the undergraduates matriculating at HBCUs and at many predominantly non-Hispanic European American (EA) institutions. Riegle-Crumb suggests that, "What is holding minority students' back is not a lack of interest in science but rather the fact that educational disadvantages are cumulative in nature, so that failures or low performance early on in school make it difficult for them to attain the prerequisites they need to continue" [24]. To date, there has been a paucity of effective solutions to resolving this decline. This report details an approach that may contribute toward resolving the low numbers of STEM discipline graduates among AA college students.

Minority students cannot earn graduate STEM degrees if they do not first achieve and persist in these disciplines at the undergraduate level. The process underlying achievement and persistence in STEM, begins in the first semesters of college. This is also where the problems with comprehension and retention of core genetic and genomic principles often begin and where some researchers have focused their investigations. Many minority students in their beginning years of college, attend large, lecture-based, fast-paced, hierarchically formatted classes and teacher-student style interactions [25] [26]. The usual mode of teaching emphasizes Verbal-Linguistic and Logical-Mathematical intellectual modalities, privileging students with word-smart and logic-smart learning styles. Nearly exclusive use these intelligence modalities to convey core terms, phrases, and concepts limits access to students that learn more effectively using other intellectual modalities. By "weeding out" students who learn differently and presuming that their academic abilities are inadequate [27] too many introductory courses are taught in a "sink or swim" approach, leaving students who do not rapidly comprehend key material via the traditional teaching style to quickly develop deficits in curriculum comprehension. Poor student performance can have a negative effect on self-esteem, reduce a student's initial intrinsic interest in science [27], and decrease the probability that a second STEM course will be taken [28].

\subsection{Factors Involved in Minorities Underrepresented in STEM}

The deficit in AA representation in the STEM disciplines is alarming. Among the reasons contributing to the low success rate include the fact that many AA families have lower incomes than their European American (EA) counterparts, making college tuition a more difficult hurdle [29] [30] and that many AA students enter these introductory college courses with weaker backgrounds and past academic experiences [31]. The initial competitive disadvantage many AA underclassmen face is reflected in their lower SAT scores, lower high school grade point averages, and lower participation in advanced high school math and science courses than their Asian and non-Hispanic white peers [32]-[35]. However, every year large numbers of AA students with high SAT scores, impressive high school GPAs, and success in high school honors math and science courses leave the science pipeline [27]. In addition, many studies have reported that SAT scores are less predictive of performance for AA than for EA students [32] [33] [36] [37].

We agree with Tobias' assessment that no student should be allowed to leave the sciences "without a struggle" [38]. In Tobias' review of how students experience introductory science classes, she identified two tiers. The 
"first tier" are curriculum proof and can withstand the limited focus on the two traditional modes of intelligence as a means of transmitting key scientific concepts and terminology. These students, whether AA or non-AA display adequate word-smart and logic-smart intelligences to grasp and retain the core material such that it can be applied successfully and accurately within the course and in subsequent courses. The "second tier" students are important because they have some ability for science and varying degrees of interest in pursuing science education yet, based upon their adverse experiences in introductory college science courses, these students are too frequently driven away from pursuing study in science-related fields. Invariably contributing to this disassociation are the restricted modalities of classroom instruction. Tobias suggests that if science education were to be restructured or reconfigured, many of these students would continue to pursue undergraduate science majors [38]. The curriculum, method of instruction, and evaluation techniques in the science classroom are the central problems identified by Tobias for successful "second tier" student retention. Her analysis suggests that introductory science courses are designed to eliminate all but those who are in the "first tier". The "second tier" students who participated in her study commented that one of the things they missed the most in their science classes was the sense of community with their peers [38]. This sentiment is common throughout much of the current science classroom infrastructure, reflecting the fact that many students learn best when their interpersonal intelligence is stimulated.

\subsection{Implementing a New Paradigm in STEM Discipline Teaching}

Since all students have diverse fluencies in each MI, it makes sense to address as many of these intellectual modalities as possible in our classrooms and in our lesson plans [39] [40]. All students want to frame their work in the best possible light and learn in the way that will "stick". Empowering students to learn through variable MI modalities fosters a collaborative classroom where students are comfortable experimenting and letting others experiment [40]. Gardners' theory of MI is also identified as a new paradigm shift in education as teachers’ transition from a traditional lecture style of instruction to a combination of active learning lectures employing multiple intelligence modes as conduits of key information. Gardner posits that many types of learners present in classroom setting could be overlooked when teachers limit active learning, relying only on verbal-linguistic and logical-mathematical instruction. These additional learning modes include individuals who are, according to Gardner [10]:

Visual-Spatial (Picture Smart)—students with these types of cognitive strengths learn best by drawing or visualizing things using "the mind's eye" or the experience of visual imagery. Visual people learn the most from pictures, diagrams, and other visual aids.

Auditory-Musical (Music Smart)—aural students learn using rhythm, pitch, or melody, especially by singing or listening to music. Their cognitive sensitivity to tempo, tone, timbre, cadence, and glissando are all important aids to comprehension.

Bodily-Kinesthetic (Body Smart)_body-smart students learn best through touch and movement. These people are best at processing information through the body. Sometimes kinesthetic learners work best standing up and moving rather than sitting still.

Interpersonal (People Smart)—students with well-developed people smart skills learn through relating to others by sharing, comparing, and cooperating. Interpersonal learners can make excellent group leaders and team players.

Intrapersonal (Self Smart)_intrapersonal-intelligent students learn best by working alone and setting individual goals. Intrapersonal learners are not necessarily shy; they are independent and organized, autonomous, and self-referential.

Naturalistic (Nature Smart)—naturalistic students learn by working with nature and enjoy learning about living things and natural events. They may excel in the sciences and be very passionate about environmental issues. They use the interrelationships in nature to further their understanding of more abstract concepts.

Analyzing the different type of intelligences in the class gives rise to the idea of creating a lesson plan and class activities that will not only address as many intelligences as possible to engender collective learning, but also allow each student individually to learn their own way and increase the transferring of difficult concepts in STEM disciplines. We have informally applied MI theory within the college classroom environment in an effort to improve student meta-comprehension and retention, particularly with respect to key concepts and topics in genetics and genomics. 


\section{Methods}

\subsection{Study Subjects and Research Setting}

Over 1500 US undergraduate college biology and biological anthropology students were observed over the course of several decades of university instruction. Students either volunteered or received college credit. 435 of these students were ethnically AAs, $64 \%$ females and $36 \%$ males. Students were observed in both predominantly US EA institutions of higher education and a US predominantly AA university (Howard University). All institutions were Research One universities and each university was either in the Ivy League, considered the flagship institutions within their respective states, or were the top HBCU. All courses listed were given at the undergraduate level of instruction. Table 1 details the specific courses, institutions, and numbers of AA college students observed that are reported on in this study.

Table 1. Evaluated multi-institutional genetics/genomics courses.

\begin{tabular}{|c|c|c|c|}
\hline $\begin{array}{l}\text { Reference Course with Significant } \\
\text { Genetics/Genomics Content }\end{array}$ & Institution & $\begin{array}{l}\text { Number of Years } \\
\text { of Observations }\end{array}$ & $\begin{array}{l}\text { Cumulative Number of } \\
\text { AA Students Observed }\end{array}$ \\
\hline Introductory Biology & Howard University & 1 & 21 \\
\hline Genetics & Howard University & 3 & 145 \\
\hline Biological Anthropology \& Human Evolution & Howard University & 2 & 45 \\
\hline Plant Biotechnology & Howard University & 1 & 9 \\
\hline Genetics and Human Evolution & UNC-Chapel Hill & 5 & 7 \\
\hline Genetics of Human Diversity & UNC-Chapel Hill & 5 & 5 \\
\hline Adaptation and Human Evolution & UNC-Chapel Hill & 4 & 2 \\
\hline Human-Plant Coevolution & UNC-Chapel Hill & 1 & 5 \\
\hline Biomedical Anthropology & UNC-Chapel Hill & 1 & 1 \\
\hline Introduction to Biological Anthropology & UMD-College Park & 20 & 103 \\
\hline Human Biodiversity & UMD-College Park & 15 & 10 \\
\hline Anthropology of Disease & UMD-College Park & 10 & 2 \\
\hline Applied Biological Anthropology & UMD-College Park & 5 & 1 \\
\hline Bioanthropology Literature & UMD-College Park & 1 & 1 \\
\hline Method and Theory in Biological Anthropology & UMD-College Park & 5 & 2 \\
\hline Advanced Topics in Human Biology & UMD-College Park & 3 & 2 \\
\hline Research Methods in Biological Anthropology & UMD-College Park & 15 & 7 \\
\hline Research Issues in Anthropological Genetics & UMD-College Park & 2 & 1 \\
\hline Genetics of Human Diversity & UMD-College Park & 5 & 6 \\
\hline Introduction to Biological Anthropology & UF-Gainesville & 5 & 45 \\
\hline Human Biology & UF-Gainesville & 5 & 12 \\
\hline Genetics and Nutrition in Medical Anthropology & UC-Berkeley & 4 & \\
\hline Human Biodiversity & UC-Berkeley & 4 & 3 \\
\hline TOTAL & & & 435 \\
\hline
\end{tabular}

Howard University, Washington DC 20059, USA; UNC-Chapel Hill refers to the University of North Carolina, Chapel Hill, NC 27599, USA; UMDCollege Park refers to the University of Maryland, College Park, MD 20742, USA; UF-Gainesville refers to the University of Florida, Gainesville, FL 32611, USA; UC-Berkeley refers to the University of California, Berkeley, CA 94720, USA. 


\subsection{Research Strategy}

In each institutional setting, student's poor to lukewarm performances on examinations testing their comprehension of genetic and genomic information taught in the tradition approach served as a stimulus for the development of alternative approaches. Culturally-competent examples and activities were developed in a trial-and-error fashion from a synthesis of the authors' emic view of AA culture and their scientific expertise. Potential approaches to understanding specific genetic and genomic words and concepts were conceptualized and first introduced in the classroom setting and student's initial receptivity to these memes noted. If students appeared to successfully connect with the scientific material using a particular culturally-informed alternative approach, that application was expanded and incorporated into the course classroom environment. In each case, the primary and secondary intelligence modalities employed by the students were noted. As more alternative approaches were developed and tested in this fashion, our repertoire of meaningful interventions grew. We documented these approaches, standardized their presentation, and integrated them into the curriculums.

\subsection{Results Evaluation}

After exposure to the culturally-augmented versions of the standard scientific materials in genetics and genomics, students were tested to evaluate their comprehension of key terms and concepts. The test format (multiple-choice, true/false, and short answer) was very similar between pre- and post-intervention and the results were compared. Students, post-intervention, were also challenged as to their broad ability to apply genetics and genomics perspectives in the course of discussions of such topics as human evolution and cell and molecular biology. This was done through the use of quasi-historical scenarios which they were ask to scientifically deconstruct. Two examples of these scenarios are provided below in Figure 2.

\section{Results}

Table 2 summarizes the most effective approaches developed in the course of this study to challenge AA college student comprehension of specific genetic and genomic words and concepts. Words in italics represent key terms addressed by the alternative MI approaches we developed.

Students' results on standard multiple-choice, true/false, and short essay tests were compared using the traditional teaching approach versus the results obtained using the alternative MI approaches developed in this study. In each case, there was an overall improvement in student's correct recognition of core genetic and genomic terms and understanding of fundamental principles. Students' deconstructions of the scenarios were used to provide insight into their broader abilities to correctly identify and apply embedded key genetics and genomics

Table 2. Culturally competent applications of MI modalities in genetics/genomics.

\begin{tabular}{|c|c|c|}
\hline $\begin{array}{l}\text { MI Modality Used (Exclusive } \\
\text { of Verbal-Linguistic and } \\
\text { Logical-Mathematical) }\end{array}$ & $\begin{array}{l}\text { Specific Targeted Genetic/Genomic } \\
\text { Words and Concepts }\end{array}$ & Culturally-Competent Application \\
\hline Visual-Spatial Intelligence & $\begin{array}{l}\text { Molecular evolution and population } \\
\text { genetics (e.g., biological coalescence theory) }\end{array}$ & $\begin{array}{c}\text { Development of physical models to represent } \\
\text { the historical merging of lineages while incorporating } \\
\text { unique aspects of AA population history. }\end{array}$ \\
\hline $\begin{array}{l}\text { Auditory-Musical } \\
\text { Intelligence }\end{array}$ & $\begin{array}{l}\text { Genomic processes (e.g., gradualism, } \\
\text { punctuated evolution, adaptation, genetic drift, } \\
\text { mutation, coevolution, stasis, randomness) }\end{array}$ & $\begin{array}{l}\text { Use of different percussion sounds at variable } \\
\text { frequencies and intensities to imitate changes } \\
\text { in gene frequencies associated with adaptation over time. }\end{array}$ \\
\hline $\begin{array}{l}\text { Bodily-Kinesthetic } \\
\text { Intelligence }\end{array}$ & $\begin{array}{l}\text { Human chromosome behavior (e.g., Mitosis, } \\
\text { meiosis), Molecular management of gene } \\
\text { regulation (e.g., transcription, translation) }\end{array}$ & $\begin{array}{l}\text { Performance of a choreographed dance to funk genre } \\
\text { (e.g. a blend of soul, jazz and rhythm and blues music) } \\
\text { with shifting rhythms and call out verbalizations. }\end{array}$ \\
\hline Interpersonal Intelligence & $\begin{array}{l}\text { DNA structure, replication, } \\
\text { and DNA manipulation }\end{array}$ & Collaboration in the composition of spoken word raps. \\
\hline Intrapersonal Intelligence & $\begin{array}{c}\text { Genetic code } \\
\text { (e.g., structure, function, interactions) }\end{array}$ & $\begin{array}{c}\text { Focus on the individual } \\
\text { (e.g., who am I, why am I special and unique?) }\end{array}$ \\
\hline Naturalistic Intelligence & $\begin{array}{l}\text { Genetic linkage and mapping } \\
\text { (e.g., protein synthesis, DNA replication, } \\
\text { recombination, crossing-over) }\end{array}$ & $\begin{array}{l}\text { Use of cultural metaphors and narratives in the } \\
\text { AA oral tradition involving Nature and } \\
\text { naturalistic phenomena, including the themes } \\
\text { of popular stories of comedic routines. }\end{array}$ \\
\hline
\end{tabular}


The purpose of this exercise is to identify various mechanisms of potential evolutionary importance in human multigenerational history. Read each scenario carefully and note situations within which such mechanisms as natural selection, genetic drift, gene flow, and mutation may be influencing the population biology of the groups under consideration. Discuss your insights fully in one-page essays (one essay per scenario) and justify your assertions. Include graphics depicting the changes in gene frequencies, if you like. Please turn in this assignment at the beginning of your next lab session.

Scenario 1: 25,000 years B.P. (before present), a group of 50 northeast Asian men, women and children has just succeeded in crossing a temporary land bridge near the current day Bearing Straits. As they travel east and then southeast following herds of wooly mammoths into modern-day Alaska, an unexpected blizzard disorients the group, they lose track of the mammoths, and they seek refuge in an isolated inland valley during the extended months of the storm. Under conditions of extreme cold, they subsist entirely off of the valley's rodents and other small mammals. Stranded all winter, two elderly members of the group do not survive. The following spring, a zoonotic (=animal derived) epidemic kills all of the children and all but three of the women. The surviving women are all full biological sisters. The children subsequently born to these three sisters over the next 25 years carry on the group's traditions including honoring the three sisters as the founding mothers of the new colony. Over many generations, these three women become immortalized as goddesses and stories relating their survival in a new environment become a core part of the group's spiritual beliefs. The three surviving sisters disproportionately contribute both biological and cultural information of relevance to the next generation. Identify which major evolutionary processes have influenced the gene pool of the group over time and state why. Consider the impact of evolutionary processes on individuals on the dynamics of the group as a whole.

Scenario 2: The time is 250 years B.P. As the great Zulu nation pushes southward deeper into modern day Azania (South Africa), the Khoi and San speaking peoples (!Kung speakers) retreat into remote and nearly uninhabitable regions of the Kalahari Desert. Zulu raids into these regions and the subordination of the Khoi and San result in some Khoi and San women being incorporated into the large, militaristic Zulu nation. Most Khoi and San, however prefer the protection of isolation and manage to survive in these ecologically very marginal areas. Subsequent to the southward expansion of Bantu-speaking Zulu peoples, Europeans from the Netherlands and the British Isles arrive, further squeezing the Khoi and San into areas where food is of limited quantity and quality. As Khoi and San lands are increasingly restricted, nearly all cultural Khoi and San are found living in the less desirable semi-arid regions of the area. The main food here is a particular root known to have mutagenic properties. After generations of residence in these areas, the Khoi and San peoples become physically smaller; smaller individuals appear to better survive under these specific desert conditions. What kinds of evolutionary processes are in operation in these groups (Zulus, Europeans, as well as !Kung speakers)? Discuss population fluctuations, effects on gene frequencies, and within group diversity. Justify your answers.

Figure 2. Deconstructing scenarios.

perspectives. After the application of our MI-focused alternative approaches, 95\% of the students showed improvements in this area $(\mathrm{N}=413)$. 370 of the AA students observed $(>85 \%)$ indicated that they benefited from the use of culturally-competent examples and activities to supplement the traditional teaching approach.

\section{Discussion}

We have found that strategies that counter traditional teaching styles by incorporating MI theory as a foundation in the STEM classroom can efficiently and effectively stimulate student learning. For many students, these culturally-competent applications became the primary way of understanding and retaining the genetic and genomic materials. The cultural connections imbedded in our interventions enhanced student receptivity to, understanding, and retention of educational material that was previously less accessible. Our research suggests that a number of key genomic and genetic topics can be better initially understood by students by tapping into their auditory-musical intelligence. For example, we have used differential percussion sounds at variable rhythms and frequencies of these rhythms to imitate changes in gene frequencies associated with adaptation over time. In one evolutionary scenario put to drumming, ancestral beats of African drums represent one biological population, while other biological populations are represented by beats on snares and toms. Changes in the intensity of each type of drum simulates changes associated with key concepts in molecular evolution and population genetics. For example, a particular composition may shift from slow mellow, riff oriented to a hard driving insistent drum beat to reflect the shift from evolutionary gradualism to punctuated evolution. We have used specific, repetitive rhythms to represent specific genomes and then randomly deleted elements of these rhythms over the course of a performance to depict the loss of genetic variation associated with inbreeding and genetic drift. Genomic stasis 
has been represented by the use of a steady beat without embellishment. Genetic change is reflected in fills and improvisation in the drumming.

Our study also suggests that students' bodily-kinesthetic intelligence is stimulated by the use of dance to depict foundational terms in genetics such as mitosis. Here, the various stages of this genetic process become stages in dance to a blend of old school rhythm and blues classics and new contemporary music. Choreographed group performances (i.e., urban soul line dancing) that the students themselves contribute to framing become routinized. These collaborations reinforce the transfer and retention of knowledge [41]. Dance provides a collective synchronous effort that helps students retain the proper sequence of events (e.g., if one person forgets, the group provides a reminder), stimulating interpersonal intelligence modality. Movement is concentrated on the hips, shoulders swaying, arms outstretched, fingers clicking, and heads tilted. Dancers become chromosomes. Since the dance stages are accompanied by changes in the tempo and rhythm of the dance music, this approach also stimulates students' auditory-musical intelligence. The more MI modalities that are engaged in any one application, the greater the student retention of information.

We have found that conveying key foundational concepts in genetics and genomics is greatly facilitated by storytelling. This taps into the historically-relevant oral tradition in many AA families. The historical creativity of AA riddles, songs, jokes and tall tales provide a template for classroom narratives of protein synthesis, DNA replication, and the epigenome. Furthermore, since many narratives of the AA oral tradition involve Nature and naturalistic phenomena, historical examples such as Bruh Rabbit, John the trickster, Ol'Mas, Uncle Rhemus' animal tales, can appeal to students' naturalistic intelligence. More relevant, however are the contemporary folk examples of guile and wit in the face of seemingly insurmountable odds. Here we reference the tradition of oral storytelling in the routines of influential comedians Richard Pryor, Eddie Murphy, Dave Chappelle, Kevin Hart, Dick Gregory, Bill Cosby, Chris Rock, Cedric the Entertainer, among others whose insights on AA life provide metaphors for human genetic and genomic processes. As these stories are "retold" in a genetics and genomics context, students recognize the familiar format and the scientific material becomes just another expression of their own life story.

Our research suggests that employing culturally-reinforcing techniques the appeal to multiple intelligence modalities in conveying fundamental concepts in genetics and genomics can build a sense of community among the students, increase the their recognition and retention of the academic material, and enhance their "ownership" of this knowledge. Cultural competence in the application of alternative modalities of leaning, especially with genetics and genomics information, can transform these materials from obstacles to further work in the STEM disciplines to conduits for further study. When students feel that the science is not only accessible, but also addressed to their realities, the terms and concepts are no longer culturally alien and a negation of group identity.

\section{Conclusions}

Understanding key concepts in genetics and genomics is fundamental to success in many of the STEM disciplines (as we have depicted in Figure 1). For many students, it is essential that we expand the previous Eurocentric paradigm of traditional lectured style learning that is only responsive to the verbal-linguistic (word smart) and logical-mathematical (number smart) intelligences.

Our research examines the "leaky pipeline" associated with AAs and STEM disciplines and suggests the use of culturally-competent, modernized strategies to increase learning comprehension and retention of difficult concepts in genetics and genomics as keys to success. Our multi-institutional data suggest that incorporating aspects of the cultural histories of AAs can have a positive impact on the inclusion of ethnic minority students in the college science classroom and produce improvements in the overall performance of these students.

Further studies will be needed to quantify the impacts of specific MI-enhanced lesson plans in a wide variety of STEM courses offered to AA undergraduates. This vulnerable group has been inadequately studied and little data exist on the impact of pedagogy on targets of AA learning efficacy. Given the primacy of genetics and genomics in $21^{\text {st }}$ Century life sciences and the current stumbling block these concepts present to many AA college biology students, this deficiency must be addressed if we are to sustainably stimulate AA college student engagement and success in the STEM disciplines.

\section{Acknowledgements}

We thank the many students that were trained over 35 years of introductory biology and biological anthropology 
courses, particularly in the department of anthropology at the University of Maryland and the department of biology at Howard University. We thank Dr. Clarence Lee and Dr. Kamila B. Deonauth for their mentorship and support of this research. We thank the Center for the Integration of Research Teaching and Learning (CIRTL) (Howard University), the Alliance for Graduate Education and the Professorate (Howard University) for providing the Effective Teaching with Technology course (JJ), and the Academy for Excellence in Teaching and Learning (University of Maryland) (FJ). Funding to publish our finding came from the department of biology research start-up monies (FJ).

\section{References}

[1] Flores, F., Tovar, M. and Gallegos, L. (2003) Representation of the Cell and Its Processes in High School Students: An Integrated View. International Journal of Science Education, 25, 269-286. http://dx.doi.org/10.1080/09500690210126793

[2] Lewis, J. and Wood-Robinson, C. (2000) Genes, Chromosomes, Cell Division and Inheritance-Do Students See Any Relationship? International Journal of Science Education, 22, 177-195. http://dx.doi.org/10.1080/09500690210126793

[3] Marbach-Ad, G. and Stavy, R. (2000) Students Cellular and Molecular Explanations of Genetic Phenomena. Journal of Biological Education, 34, 200-205. http://dx.doi.org/10.1080/00219266.2000.9655718

[4] Dikmenli, M. (2009) Misconceptions of Cell Division Held by Student Teachers in Biology: A Drawing Analysis. Academic Journals: Scientific Research and Essay, 5, 235-247.

[5] Oztas, H., Ozay, E. and Oztas, F. (2003) Teaching Cell Division to Secondary School Students: An Investigation of Difficulties Experienced by Turkish Teachers. Journal of Biological Education, 38, 13-15. http://dx.doi.org/10.1080/00219266.2003.9655890

[6] Newman, D.L. (2012) Students Fail to Transfer Knowledge of Chromosome Structure to Topics Pertaining to Cell Division. Rochester Institute of Technology, New York.

[7] Mills Shaw, K.R., Van Horne, K., Zhang, H. and Boughman, J. (2008) Essay Contest Reveals Misconceptions of High School Students in Genetics Content. Genetics, 178, 1157-1168. http://dx.doi.org/10.1534/genetics.107.084194

[8] Bahar, M. (2003) Misconceptions in Biology Education and Conceptual Change Strategies. Education, Science Theory \& Practice, 3, 55-64.

[9] Wandersee, J.H., Mintzes, J.J. and Novak, D. (1994) Research on Alternative Conceptions in Science. In: Gabel, D.L., Ed., Handbook of Research on Science Teaching and Learning, Macmillan, New York, 177-210.

[10] Gardner, H. (1983) Frames of Mind: The Theory of Multiple Intelligences. Perseus Book Group, Basic Books, New York.

[11] Campbell, B. (2013) Multiple Intelligences in the Classroom: Of the Seven Different Ways We Learn, Schools Focus on Only Two. Add the Other Five, and You Increase the Chances of Success. http://www.context.org/iclib/ic27/campbell/

[12] Mullich, J. (2013) Rising to the Challenge-America's Math and Science Curriculum Is Key to Future Competitiveness. http://online.wsj.com/ad/article/mathscience-rising

[13] Cañas, A.J., Novak, J.D. and González, F.M. (2004) Concept Maps: Theory, Methodology, Technology. Proceedings of the First International Conference on Concept Mapping, Editorial Universidad Pública de Navarra.

[14] Tekkaya, C. (2003) Remediating High Schools’ Misconceptions Concerning Diffusion and Osmosis through Concept Mapping and Conceptual Change Text. Research in Science \& Technological Education, 21, 5-16. http://dx.doi.org/10.1080/02635140308340

[15] Barrington, E. (2004) Teaching to Student Diversity in Higher Education: How Multiple Intelligence Theory Can Help. Teaching in Higher Education, 9, 421-434. http://dx.doi.org/10.1080/1356251042000252363

[16] Riemeier, T. and Gropengieber, H. (2008) On the Roots of Difficulties in Learning about Cell Division: Process-Based Analysis of Students’ Conceptual Development in Teaching Experiments. International Journal of Science Education, 30, 923-939. http://dx.doi.org/10.1080/09500690701294716

[17] Bahar, M., Ozel, M., Prokop, P. and Usak, M. (2008) Science Student Teachers' Ideas of the Heart. Journal of Baltic Science Education, 7, 78-85.

[18] Bowker, R. (2007) Children's Perceptions and Learning about Tropical Rainforests: An Analysis of Their Drawings. Environmental Education Research, 13, 75-96. http://dx.doi.org/10.1080/13504620601122731

[19] Kose, S. (2008) Diagnosing Student Misconceptions: Using Drawings as a Research Method. World Applied Sciences Journal, 3, 283-293.

[20] Reiss, M.J. and Tunnicliffe, S.D. (2001) Students’ Understandings about Human Organs and Organ Systems. Research 
in Science Education, 31, 383-399. http://dx.doi.org/10.1023/A:1013116228261

[21] National Academies (2010) Rising above the Gathering Storm, Revisited: Rapidly Approaching Category 5. The National Academies Press, Washington DC, $104 \mathrm{p}$.

[22] National Academy of Sciences, National Academy of Engineering and Institute of Medicine (2010) US Competitive Position Has Further Declined in Past Five Years, Report Says; Nation Needs Sustain Commitment to Investment in Innovation. News from the National Academies. http://www8.nationalacademies.org/onpinews/newsitem.aspx?RecordID=12999

[23] National Science Foundation, National Center for Science and Engineering Statistics (2013) Women, Minorities, and Persons with Disabilities in Science and Engineering. Special Report NSF 13-304, Arlington, VA. http://www.nsf.gov/statistics/wmpd/

[24] Sasso, A. (2008) African Americans Studying STEM: Parsing the Numbers. Science Careers, Career Magazine, Diversity Issues. http://sciencecareers.sciencemag.org/career_magazine/previous_issues/articles/2008_05_16/caredit.a0800070

[25] Barr, R.B. and Tagg, J. (1995) From Teaching to Learning: A New Paradigm for Undergraduate Education. Journal of Change, Research Library Core, 12 p. http://www.athens.edu/visitors/QEP/Barr_and_Tagg_article.pdf

[26] Wineke, W.R. and Certain, P. (1990) The Freshman Year in Science and Engineering: Old Problems, New Perspectives for Research Universities. Alliance for Undergraduate Education, ERIC, University Park, 57.

[27] Seymour, E. and Hewitt, N.M. (1997) Talking about Leaving: Why Undergraduates Leave the Sciences. Westview Press, Boulder.

[28] Sabot, R. and Wakeman-Linn, J. (1991) Grade Inflation and Course Choice. Journal of Economic Perspectives, 5, 159170. http://dx.doi.org/10.1257/jep.5.1.159

[29] Astin, A.W. (1982) Minorities in American Higher Education: Recent Trends, Current Perspectives, and Recommendations. Jossey-Bass, San Francisco.

[30] Astin, A.W. (1990) The Black Undergraduate: Current Status and Trends in the Characteristics of Freshmen. University of California Los Angles, Higher Education Research Council, Los Angles.

[31] Maton, K.I., Hrabowski, F.A. and Schmitt, C.L. (2000) African American College Students Excelling in the Sciences: College and Postcollege Outcomes in the Meyerhoff Scholars Program. Journal of Research in Science Teaching, 37, 629-654. http://dx.doi.org/10.1002/1098-2736(200009)37:7<629::AID-TEA2>3.0.CO;2-8

[32] Willingham, W.W., Lewis, C., Morgan, R. and Ramist, L. (1990) Predicting College Grades: An Analysis of Institutional Trends over Two Decades. Educational Testing Service, Princeton, 253-288.

[33] Ramist, L., Lewis, C. and McCamley-Jenkins, L. (1994) Student Group Differences in Predicting College Grades: Sex, Language, and Ethnic Groups. College Board Report No. 93-1, College Entrance Examination Board, New York.

[34] Elliott, R., Strenta, A.C., Adair, R., Matier, M. and Scott, J. (1995) Non-Asian Minority Students in the Science Pipeline at Highly Selective Institutions. Report to the NSF, National Science Foundation, Washington DC.

[35] Gandara, P. and Maxwell-Jolly, J. (1999) Priming the Pump: A Review of Programs That Aim to Increase the Achievement of Underrepresented Minority Undergraduates. A Report to the Task Force on Minority High Achievement of the College Board, College Board, New York.

[36] Breland, H.M. (1979) Population Validity and College Entrance Measures. College Entrance Examination Board, New York.

[37] Bowen, W.G. and Bok, D. (1998) The Shape of the River: Long-Term Consequences of Considering Race in College and University Admissions. Princeton University Press, Princeton.

[38] Astin, A.W. and Astin, H.S. (1992) Undergraduate Science Education: The Impact of Different College Environments in the Educational Pipeline in the Sciences. Final Report, National Science Foundation, Washington DC. www.seaphe.org/pdf/astin.pdf

[39] Ostwald-Kowald, T. (2014) Understanding Your Students Learning Style: The Theory of Multiple Intelligences. http://www.connectionsacademy.com/blog/posts/2013-01-18/Understanding-Your-Student-s-Learning-Style-The-Theo ry-of-Multiple-Intelligences.aspx

[40] Borek, J. (2003) Inclusion and the Multiple Intelligences: Creating a Student-Centered Curriculum. The Quarterly, 25, 24-28.

[41] Bella, T., Urhahneb, D., Schanzec, S. and Ploetznerd, R. (2009) Collaborative Inquiry Learning Models, Tools, and Challenges. International Journal of Science Education, 32, 349-377. http://dx.doi.org/10.1080/09500690802582241 